J. Dairy Sci. 98:2401-2408

http://dx.doi.org/10.3168/jds.2014-8727

(C) American Dairy Science Association ${ }^{\circledR}, 2015$.

\title{
Flow cytometric analysis: Interdependence of healthy and infected udder quarters
}

\author{
M. G. Blagitz, ${ }^{* 1,2}$ F. N. Souza, $\dagger^{2}$ C. F. Batista, ${ }^{*}$ S. A. Diniz, $\dagger$ L. F. F. Azevedo, ${ }^{*}$ M. X. Silva, $\dagger$ J. P. A. Haddad, $\dagger$ \\ M. B. Heinemann, $\uparrow$ M. M. O. P. Cerqueira, $†$ and A. M. M. P. Della Libera* \\ *Departamento de Clínica Médica, Faculdade de Medicina Veterinária e Zootecnia, Universidade de São Paulo, \\ Av. Prof. Dr. Orlando Marques de Paiva, 87, Cidade Universitária, São Paulo 05508-270, Brazil \\ †Escola de Veterinária, Universidade Federal de Minas Gerais, Belo Horizonte 31270-010, Brazil
}

\begin{abstract}
An important question about intramammary infections that is still debated in the literature is the independence or interdependence of the quarters of dairy cows. The present study sought to explore milk neutrophil function and the milk lymphocyte profile of uninfected quarters from uninfected and infected (one infected quarter per cow) udders to evaluate interdependence of the quarters. Thus, 32 (8 cows) and 18 (6 cows) uninfected quarters from uninfected and infected udders were used, respectively. Using flow cytometry, we evaluated the percentage of milk neutrophils and their expression of adhesion molecules L-selectin (CD62L), $\beta_{2}$-integrin (CD11b), and an endothelial-selectin ligand (CD44); levels of intracellular reactive oxygen species (ROS); phagocytosis of Staphylococcus aureus by milk neutrophils; and neutrophil viability. Furthermore, we assessed the percentage of B-cell $\left(\mathrm{CD} 21^{+}\right)$and T-lymphocyte subsets $\left(\mathrm{CD}^{+} / \mathrm{CD}^{+} / \mathrm{CD} 8^{-}, \mathrm{CD}^{+} / \mathrm{CD}^{+} /\right.$ $\mathrm{CD} 4^{-}, \mathrm{CD}^{+} / \mathrm{CD} 4^{+} / \mathrm{CD} 25^{-}, \mathrm{CD}^{+} / \mathrm{CD} 4^{+} / \mathrm{CD} 25^{+}$, and $\mathrm{CD}^{+} / \mathrm{CD}^{-} / \mathrm{CD} 25^{-}$) using flow cytometry with monoclonal antibodies. The infected quarter did not affect somatic cell count or the percentage of neutrophils in the neighboring uninfected quarters. Furthermore, the infected quarter did not influence neutrophil viability, intracellular reactive oxygen species production, or phagocytosis of $S$. aureus by milk neutrophils. Conversely, the expression of adhesion molecules CD11b, CD62L, and CD44 by milk neutrophils differed between uninfected quarters from infected versus uninfected udders. The lymphocyte subsets did not differ between groups, except for a higher percentage of B cells in uninfected quarters from infected udders than in those from
\end{abstract}

Received August 9, 2014.

Accepted January 5, 2015.

${ }^{1}$ Corresponding author: magblagitz@uol.com.br

${ }^{2}$ These authors contributed equally to the paper. uninfected udders. Thus, our study strongly supports the hypothesis of interdependence of quarters based on the influence of infection on both the percentage of $\mathrm{B}$ cells and the expression of adhesion molecules by milk neutrophils in the neighboring uninfected quarters.

Key words: mastitis, somatic cell count, lymphocyte, neutrophil, dairy cow

\section{INTRODUCTION}

Several previous studies have evaluated aspects of IMI based on the assumption that quarters within a cow are independent of each other (Berry and Meaney, 2006; Jensen et al., 2013) because of the anatomical construction of the udder, which implies that the infection of one quarter does not influence the immune status of the neighboring quarters (Merle et al., 2007; Jensen et al., 2013). An important question about IMI that is still debated in the literature is the independence or interdependence of the quarters of dairy cows (Schwarz et al., 2011). For instance, does a local inflammatory response against invading bacteria in an infected quarter influence the immune response of neighboring uninfected quarters? If it does, the local cross talk between udder quarters could be responsible for priming the neighboring uninfected quarters and therefore may influence the immune response against new infections. Some studies have evaluated the interdependence of quarters by determining the probability of an infection spreading from an infected to an uninfected quarter (Barkema et al., 1997; Sol et al., 2000; Berry and Meaney, 2006) or by evaluating milk SCC (Wever and Emanuelson, 1989), percentage of immune cells, or certain immune response parameters (Merle et al., 2007; Schwarz et al., 2011). The reasons that uninfected quarters from infected udders are more likely to be contaminated than quarters from uninfected udders may include the animal's susceptibility to mastitis, the transmission patterns of infection, or inherent immune competency (Barkema et al., 1997; Berry and Meaney, 2006). The transmission pattern of IMI in particular, 
should be considered, given the contagious behavior of pathogens and the fact that transmission occurs not only between cows but also between quarters within a cow (Barkema et al., 1997).

The aim of this study was to better elucidate the interdependence of quarters, exploring milk neutrophil function and milk lymphocyte profiles in uninfected quarters from infected and uninfected udders using flow cytometry analysis. To our knowledge, this is the first study to perform a broad evaluation of milk neutrophil function and milk lymphocyte subsets in uninfected quarters from udders with different infectious statuses. We believe that this new knowledge may improve the understanding of the interdependence of quarters, which may influence the probability of new infections in uninfected quarters.

\section{MATERIALS AND METHODS}

\section{Animals}

The present study used 50 mammary quarters from 14 Holstein dairy cows, which were collected at different lactation stages (DIM) and parities from a commercial dairy herd in São Paulo State, Brazil. The milk samples were divided into groups 1 and 2 as follows: group 1 included culture-negative milk samples from quarters of uninfected udders with no abnormal secretions in the strip cup test ( $\mathrm{n}=32$ quarters; 8 dairy cows); and group 2 included culture-negative milk samples with $\mathrm{SCC}<1 \times 10^{5}$ cells $/ \mathrm{mL}$ from quarters from infected udders (only 1 quarter was considered as infected) with no abnormal secretions in the strip cup test $(\mathrm{n}=18$ quarters; 6 dairy cows). All cows with more than one infected quarter were excluded from this study.

\section{Sample Collection}

First, the strip cup test was performed to identify the presence of clots, flakes, or otherwise obviously abnormal secretions. Predipping was then performed, with one towel used for each teat. After discarding the first 3 milk streams, teat ends were scrubbed with cotton soaked in $70 \%$ ethanol, and a single milk sample from each mammary quarter was aseptically collected into sterile vials for bacteriological analysis. Finally, milk samples were collected for evaluation of SCC (40 mL), neutrophil function, and milk lymphocyte profiles $(1 \mathrm{~L}$ of milk). The samples were kept at $4^{\circ} \mathrm{C}$ until arrival at the laboratory. The milk samples for the bacteriological analysis were collected once on the same day as those for analysis of immune parameters and were stored at $-20^{\circ} \mathrm{C}$ for up to $30 \mathrm{~d}$ until the analysis.

\section{Bacteriological Analysis}

Bacteriological analysis was performed by culturing $0.01 \mathrm{~mL}$ of each milk sample on $5 \%$ sheep blood agar plates. The plates were incubated for $72 \mathrm{~h}$ at $37^{\circ} \mathrm{C}$, followed by Gram staining, observation of colony morphologies, and biochemical testing (Oliver et al., 2004). A milk sample was considered culture-positive when the growth of $\geq 3$ colonies was detected, except for animals with Staphylococcus aureus or Streptococcus agalactiae infections in their quarters, which were considered culture-positive when the growth of $\geq 1$ colony was detected (Piepers et al., 2007; Piepers and De Vliegher, 2013).

\section{Determination of SCC}

Milk samples for SCC determination were collected in $40-\mathrm{mL}$ vials containing microtablets of the preservative bronopol (2-bromo-2-nitropane-1,3-diol). Subsequently, the SCC analysis was performed using a Somacount 300 automated somatic cell counter (Bentley Instruments, Chaska, MN).

\section{Definition of IMI Status}

A quarter was considered uninfected when it was culture-negative, with no abnormal secretions in the strip cup test, and had a milk SCC $\leq 1 \times 10^{5}$ cells $/ \mathrm{mL}$, as the threshold for an uninfected quarter proposed by Bansal et al. (2005). A quarter was considered infected when any mastitis pathogen was isolated from a single milk sample or it had SCC $>2 \times 10^{5}$ cells $/ \mathrm{mL}$, as the threshold for an uninfected quarter as proposed by Schepers et al. (1997) and Schukken et al. (2003).

\section{Separation of Milk Cells}

The separation of the milk cells was performed as described by Koess and Hamann (2008). Briefly, $1 \mathrm{~L}$ of milk was diluted with $1 \mathrm{~L}$ of PBS (pH 7.4; $1.06 \mathrm{mM} \mathrm{Na}_{2} \mathrm{HPO}_{4}$, $155.17 \mathrm{mM} \mathrm{NaCl}$, and $\left.2.97 \mathrm{~m} M \mathrm{Na}_{2} \mathrm{HPO}_{4} \cdot 7 \mathrm{H}_{2} \mathrm{O}\right)$. After centrifugation at $1,000 \times g$ for $15 \mathrm{~min}$, the cream layer and supernatant were discarded. The cell pellet was then washed once using $30 \mathrm{~mL}$ of PBS and centrifuged at $400 \times g$ for $10 \mathrm{~min}$. The cells were resuspended in 1 $\mathrm{mL}$ of RPMI-1640 nutritional medium (R7638, Sigma Aldrich, St. Louis, MO) supplemented with $10 \%$ fetal bovine serum (Cultilab, Campinas, Brazil) and counted using a Neubauer chamber. Cell viability was evaluated using trypan blue exclusion. The milk cells were then diluted with nutritional medium containing $10 \%$ fetal bovine serum to a concentration of $2 \times 10^{6}$ viable cells/ $\mathrm{mL}$. 


\section{Enumeration of Lymphocyte Subpopulations}

The cells were washed with PBS and stained to detect $\mathrm{CD} 21$, the combination of CD3, CD4, and CD8, and the combination of CD3, CD4, and CD25 following incubation with the primary antibodies (Ab) for 30 min on ice. The identification of lymphocyte subsets was based on their cytoplasmic granularities and mean fluorescence intensities following a 2-step fluorescence immunolabeling protocol using primary anti-bovine monoclonal Ab ( $\mathbf{m A b})$ and secondary Ab coupled to long-wavelength fluorescent probes (Table 1). Thereafter, $1 \mathrm{~mL}$ of PBS was added to cell suspension and centrifuged at $400 \times g$ for $8 \mathrm{~min}$. Finally, the labeled secondary Ab was added to cell suspension and the cells were incubated for $30 \mathrm{~min}$ on ice with the secondary Ab. The cells were then washed with PBS and immediately analyzed using flow cytometry. In total, 20,000 milk cells, excluding most of the cellular debris, were examined per sample. FlowJo software (TreeStar Inc., Ashland, OR) was used to analyze the data. The results were corrected for autofluorescence, which was defined as the fluorescence that was associated with nonlabeled, freshly isolated milk cells from the same cow (Della Libera et al., 2015).

\section{Identification of Neutrophils}

Milk neutrophils were differentiated from other cells by indirect fluorescence labeling. The cells were incubated with an unlabeled primary monoclonal antibovine granulocyte antibody (Table 1) for 30 min on ice temperature. Next, $1 \mathrm{~mL}$ of PBS was added to the cell suspension, which was centrifuged at $400 \times g$ for 8 min. Finally, a labeled secondary Ab (Table 1) was added, and the sample was incubated for $30 \mathrm{~min}$ on ice in the dark to visualize the bound CH138A. The neutrophils were identified using flow cytometry based on the cells' cytoplasmic granularities and $\mathrm{CH} 138 \mathrm{~A}$ positivity as previously described (Piepers et al., 2009; Blagitz et al., 2013). The flow cytometry data analysis was performed as described above.

\section{Detection of Apoptosis Using Flow Cytometry}

The death of neutrophils $\left(\mathrm{CH} 138^{+}\right)$was assessed using dual-labeling with an annexin $\mathrm{V}$ antibody and propidium iodide (PI; K2350, Apoptest-FITC, Dako Cytomation, Mijdrecht, the Netherlands) and flow cytometric analysis as previously described (Piepers et al., 2009; Blagitz et al., 2013). Briefly, $2 \times 10^{5}$ viable milk cells were suspended in $100 \mu \mathrm{L}$ of binding buffer (10 $\mathrm{m} M$ HEPES, $150 \mathrm{~m} M \mathrm{NaCl}, 1 \mathrm{mM} \mathrm{MgCl}_{2}$, and $1.8 \mathrm{mM} \mathrm{CaCl}_{2}$ ) containing anti-annexin $\mathrm{V}$-fluorescein

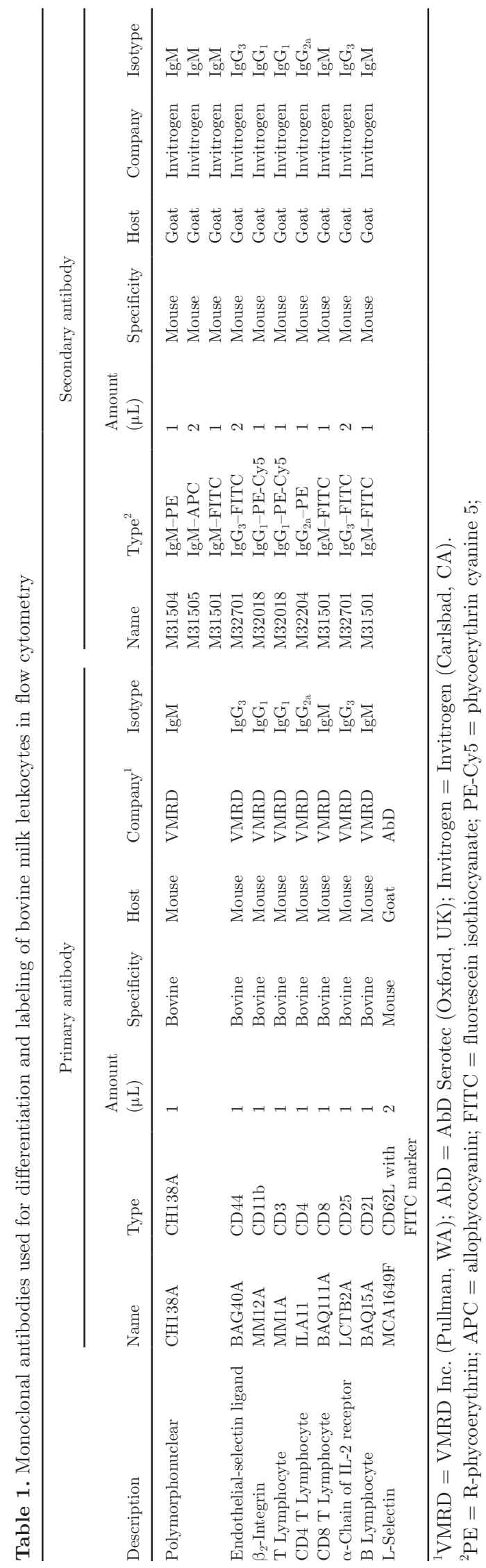

Journal of Dairy Science Vol. 98 No. 4, 2015 
isothiocyanate (FITC) antibody and incubated on ice for $20 \mathrm{~min}$ in the dark. Immediately before flow cytometric analysis, $5 \mu \mathrm{L}$ of a $250 \mu \mathrm{g} / \mathrm{mL}$ PI solution was added. Next, the neutrophils were labeled using $\mathrm{mAb}$ as described above.

To analyze the data, scatterplots were generated for the gated neutrophils. The living, nonapoptotic cells were negative for both FITC-labeled anti-annexin V and PI. The cells that were positive for FITC-labeled anti-annexin $\mathrm{V}$ but negative for PI were classified as apoptotic cells (Piepers et al., 2009; Blagitz et al., 2013). The necrotic subpopulation was excluded from analysis (Piepers and De Vliegher, 2013). The flow cytometry data analysis was performed as described above.

\section{Intracellular Reactive Oxygen Species Production}

Intracellular reactive oxygen species (ROS) production was assessed with flow cytometry using 2',7'-dichlorofluorescein diacetate (DCFH-DA) as a probe (Hasui et al., 1989). Briefly, $2 \times 10^{5}$ viable milk cells from each quarter, which were previously assessed using trypan blue exclusion, were incubated at $37^{\circ} \mathrm{C}$ for $30 \mathrm{~min}$ with $0.3 \mu M$ DCFH-DA (D6883, Sigma Aldrich).

The intracellular 2',7'-dichlorofluorescein (DCF) fluorescence of the neutrophils was determined by flow cytometry using an excitation wavelength of $488 \mathrm{~nm}$. Briefly, DCFH-DA, which is a cell-permeable, nonfluorescent probe, is converted to the fluorescent DCF by ROS in a dose-dependent manner, resulting in fluorescence emission. The green fluorescence of DCF was detected at 500 to $530 \mathrm{~nm}$.

The percentage of neutrophils producing ROS was calculated as the number of fluorescent neutrophils divided by the total neutrophil count and multiplied by 100. The median fluorescence intensity (MFI) of ROS production was estimated from the median of DCF fluorescence divided by the number of neutrophils that produced ROS (Blagitz et al., 2013; Della Libera et al., 2015). For this assay, 10,000 gated neutrophils were examined per sample. FlowJo software (TreeStar Inc.) was used to analyze the data. The results were corrected for autofluorescence content, which was defined as the fluorescence that was associated with nonlabeled, freshly isolated milk cells from the same cow.

\section{Preparation of Pl-Labeled Bacteria}

Propidium iodide-labeled Staphylococcus aureus (ATCC 25923) was prepared as described by Hasui et al. (1989) with some modifications for detection of phagocytosis of $S$. aureus by milk neutrophils. Briefly, S. aureus was cultured for $18 \mathrm{~h}$ at $37^{\circ} \mathrm{C}$ on brain-heart infusion agar. Subsequently, the bacteria were heatkilled using incubation at $60^{\circ} \mathrm{C}$ for $30 \mathrm{~min}$, after which they were washed 3 times using a sterile saline solution $(0.9 \% \mathrm{NaCl})$. The bacterial density was adjusted to an absorbance of 2.50 at $620 \mathrm{~nm}$, yielding approximately $2.4 \times 10^{9}$ bacteria $/ \mathrm{mL}$, as previously described (Hasui et al., 1989). The bacteria were then labeled using a $5 \%$ PI (P4170, Sigma Aldrich) solution for $30 \mathrm{~min}$ on ice. The fluorescent bacteria were washed 3 times and suspended in PBS containing $5 \mathrm{~m} M$ glucose and $0.1 \%$ gelatin, and aliquots were stored at $-80^{\circ} \mathrm{C}$. Thereafter, the PI labeling of the bacteria was confirmed using flow cytometry.

\section{Phagocytosis Assay}

The phagocytosis assay was performed using flow cytometry of PI-labeled S. aureus. Briefly, $2 \times 10^{5}$ viable milk cells were incubated with $100 \mu \mathrm{L}$ of heat-killed, PI-labeled S. aureus and $900 \mu \mathrm{L}$ of PBS for $30 \mathrm{~min}$ at $37^{\circ} \mathrm{C}$. Subsequently, $2 \mathrm{~mL}$ of $3 \mathrm{~m} M$ EDTA was added, and after centrifugation at $400 \times g$ for $10 \mathrm{~min}$, the leukocytes were resuspended in $300 \mu \mathrm{L}$ of PBS and analyzed using flow cytometry.

The percentage of neutrophils that phagocytized the PI-labeled bacteria was equal to the number of fluorescent neutrophils divided by the total neutrophil count and multiplied by 100 . The MFI of $S$. aureus phagocytosis was estimated from the median value of PI fluorescence divided by the number of neutrophils that phagocytized S. aureus (Blagitz et al., 2013; Della Libera et al., 2015). At least 20,000 cells were examined per sample.

\section{Expression of L-Selectin, $\beta_{2}$-Integrin, and CD44}

The identification of neutrophils expressing L-selectin (CD62L), the $\beta$-chain of $\beta_{2}$-integrin (CD11b) and 1 of the 3 endothelial-selectin ligands (CD44) was performed with flow cytometry using $\mathrm{mAb}$, as shown in Table 1. Unlabeled primary $\mathrm{mAb}$ that were directed against CH138A, CD11b, and CD44 were added to the cell suspension and incubated for $30 \mathrm{~min}$ on ice. The isolated milk cell suspension was centrifuged at $400 \times$ $g$ for $8 \mathrm{~min}$, and a labeled CD62L mAb, and secondary labeled $\mathrm{mAb}$ for the detection of the anti-CH138A, anti-CD11b, and anti-CD44 Ab were added. Finally, the isolated milk cells were incubated for $30 \mathrm{~min}$ on ice in the dark to allow for visualization of cells expressing CD62L, CD11b, and CD44. First, dot plots of gated neutrophils $\left(\mathrm{CH} 138 \mathrm{~A}^{+}\right)$were generated as previously described. We chose the relative MFI for analysis of adhesion molecules because this parameter was much 
Table 2. Parity, SCC, and function of milk neutrophils from uninfected quarters of uninfected udders and uninfected quarters of infected udders (mean $\pm \mathrm{SE}$ )

\begin{tabular}{|c|c|c|}
\hline Group/variable $^{1}$ & $\begin{array}{l}\text { Uninfected quarters from } \\
\text { uninfected udders }(\mathrm{n}=32)\end{array}$ & $\begin{array}{l}\text { Uninfected quarters from } \\
\text { infected udders }(\mathrm{n}=18)\end{array}$ \\
\hline Lactational status (DIM) & $133.38 \pm 22.84^{\mathrm{a}}$ & $188.17 \pm 31.31^{\mathrm{a}}$ \\
\hline Parity & $2.50 \pm 0.31^{\mathrm{a}}$ & $1.67 \pm 0.11^{\mathrm{a}}$ \\
\hline $\mathrm{SCC}($ cells $/ \mathrm{mL})$ & $31,313 \pm 6,225^{\mathrm{a}}$ & $24,111 \pm 7,758^{\mathrm{a}}$ \\
\hline $\mathrm{CH} 138^{+}(\%)$ & $11.52 \pm 2.70^{\mathrm{a}}$ & $6.67 \pm 1.88^{\mathrm{a}}$ \\
\hline Annexin $\mathrm{V}^{-} / \mathrm{PI}^{-}(\%)$ & $31.41 \pm 2.57^{\mathrm{a}}$ & $27.42 \pm 3.90^{\mathrm{a}}$ \\
\hline Annexin $\mathrm{V}^{+} / \mathrm{PI}^{-}(\%)$ & $43.43 \pm 3.34^{\mathrm{a}}$ & $40.33 \pm 3.96^{\mathrm{a}}$ \\
\hline ROS production $(\%)$ & $59.39 \pm 3.52^{\mathrm{a}}$ & $61.89 \pm 5.07^{\mathrm{a}}$ \\
\hline Intensity of ROS production (MFI) & $1,840 \pm 179.4^{\mathrm{a}}$ & $1,313 \pm 141.8^{\mathrm{a}}$ \\
\hline Staphylococcus aureus phagocytosis (\%) & $60.67 \pm 3.33^{\mathrm{a}}$ & $56.28 \pm 4.39^{\mathrm{a}}$ \\
\hline Intensity of $S$. aureus phagocytosis (MFI) & $201.4 \pm 19.97^{\mathrm{a}}$ & $176.82 \pm 13.82^{\mathrm{a}}$ \\
\hline CD44 expression (MFI) & $11.21 \pm 3.23^{\mathrm{a}}$ & $1.03 \pm 0.02^{\mathrm{b}}$ \\
\hline CD62L expression (MFI) & $9.32 \pm 2.54^{\mathrm{a}}$ & $1.01 \pm 0.00^{\mathrm{b}}$ \\
\hline CD11b expression (MFI) & $597.2 \pm 63.94^{\mathrm{b}}$ & $1,034 \pm 96.18^{\mathrm{a}}$ \\
\hline
\end{tabular}

a,b Means with different superscript letters within a row indicate significant differences $(P \leq 0.05)$.

${ }^{1} \mathrm{PI}=$ propidium iodide; $\mathrm{ROS}=$ reactive oxygen species; MFI $=$ median fluorescence intensity; $\mathrm{CD} 62 \mathrm{~L}=$ L-selectin; CD11b $=\beta$-chain of $\beta 2$-integrin; CD44 = 1 of the 3 endothelial-selectin ligands.

more discriminating than the percentage of positive cells. The MFI provides an accurate measurement of the brightness of the stained cells and is thus an indicator of the number of receptors per cell (Diez-Fraile et al., 2003). For this assay, 10,000 gated neutrophils were examined per sample.

\section{Statistical Analyses}

First, the distributions of all variables were examined using normal probability plots obtained using the Shapiro-Wilk test. The data were analyzed using a multivariate ANOVA. Then, the Kruskal-Wallis and Mann-Whitney tests were applied. The model considered quarters and cows to be nested within the cows as random effect. The statistical analyses were performed using STATA statistical software version 12 (Stata Corp., College Station, TX). The results are reported as the mean \pm standard error, and significance was set at $P \leq 0.05$.

\section{RESULTS}

The results are summarized in Tables 2 and 3. Somatic cell count (Table 2), lactational status, and parity values did not differ significantly between the groups (Table 2). Regarding the infected quarters in group 2 $(\mathrm{n}=6)$, in 2 quarter milk samples were isolated $\mathrm{Co}$ rynebacterium bovis, and 4 milk quarters samples had unspecific mastitis on the day of investigation (SCC $>2 \times 10^{5}$ cells $/ \mathrm{mL}$ ). Two out of these quarters with unspecific mastitis were affected by clinical mastitis.

We found that uninfected quarters from infected udders had high levels of CD11b expression by milk neutrophils, in contrast to the high levels of CD62L and CD44 expressed by milk neutrophils from uninfected quarters of uninfected udders. No significant difference was observed in the percentage of milk neutrophils $\left(\mathrm{CH} 138^{+}\right)$, neutrophil viability (annexin $\mathrm{V}^{-} / \mathrm{PI}^{-}$) and apoptosis (annexin $\mathrm{V}^{+} / \mathrm{PI}^{-}$), intracellular ROS production, or $S$. aureus phagocytosis (Table 2).

Table 3. Percentage (mean \pm SE) of milk lymphocyte subpopulations from uninfected quarters of uninfected udders and uninfected quarters of infected udders

\begin{tabular}{lcc}
\hline Subpopulation & $\begin{array}{c}\text { Uninfected quarters from } \\
\text { uninfected udders }(\mathrm{n}=32)\end{array}$ & $\begin{array}{c}\text { Uninfected quarters from } \\
\text { infected udders }(\mathrm{n}=18)\end{array}$ \\
\hline $\mathrm{CD}^{+}$(T cells) & $9.05 \pm 1.10^{\mathrm{a}}$ & $8.65 \pm 1.34^{\mathrm{a}}$ \\
$\mathrm{CD} 4^{+} / \mathrm{CD} 8^{-} \mathrm{T}$ cells & $1.57 \pm 0.26^{\mathrm{a}}$ & $1.72 \pm 0.54^{\mathrm{a}}$ \\
$\mathrm{CD} 4^{-} / \mathrm{CD} 8^{+} \mathrm{T}$ cells & $3.70 \pm 0.42^{\mathrm{a}}$ & $3.66 \pm 0.85^{\mathrm{a}}$ \\
$\mathrm{CD} 3^{+}$(T cells) & $8.21 \pm 0.99^{\mathrm{a}}$ & $8.91 \pm 1.47^{\mathrm{a}}$ \\
$\mathrm{CD}^{+} / \mathrm{CD} 25^{-}$T cells & $1.66 \pm 0.26^{\mathrm{a}}$ & $1.80 \pm 0.56^{\mathrm{a}}$ \\
$\mathrm{CD} 4^{+} / \mathrm{CD} 25^{+}$T cells & $0.26 \pm 0.05^{\mathrm{a}}$ & $0.15 \pm 0.03^{\mathrm{a}}$ \\
$\mathrm{CD} 4^{-} / \mathrm{CD} 25^{-} \mathrm{T}$ cells & $6.18 \pm 0.78^{\mathrm{a}}$ & $6.85 \pm 1.04^{\mathrm{a}}$ \\
$\mathrm{CD} 21^{+}$(B cells) & $10.47 \pm 1.45^{\mathrm{b}}$ & $12.26 \pm 1.07^{\mathrm{a}}$ \\
\hline
\end{tabular}

${ }^{\mathrm{a}, \mathrm{b}}$ Means with different superscript letters within a row indicate significant differences $(P \leq 0.05)$. 
Lymphocyte subsets did not differ between the groups, except that the percentage of B cells was higher in uninfected quarters from infected udders than in uninfected quarters from uninfected udders (Table 3).

\section{DISCUSSION}

We investigated milk neutrophil function and lymphocyte profile in uninfected quarters from uninfected and infected udders. Our data indicate that the immune response in the udder quarters does not act independently but is influenced by IMI of neighboring quarters, even though quarters appear to act as independent units in terms of the anatomical structure of the mammary gland.

In the present study, the infected quarter did not influence SCC, percentage of neutrophils, neutrophil viability, intracellular ROS production, or phagocytosis of $S$. aureus by milk neutrophils in the neighboring uninfected quarters. It is well known that apoptosis of bovine neutrophils implies impaired phagocytic and oxidative burst activities (Van Oostveldt et al., 2002; Mehrzad et al., 2005). Thus, the nonsignificant difference observed in neutrophil viability rates between the groups in this study may be related to the results for the percentage of neutrophils that produced ROS or phagocytized $S$. aureus, because neutrophil viability is closely related to neutrophil phagocytosis and oxidative burst activities (Mehrzad et al., 2004, 2005).

Furthermore, the inclusion of milk samples with a low threshold for SCC $\left(\leq 1 \times 10^{5}\right.$ cells $\left./ \mathrm{mL}\right)$ may lead to nonsignificant difference in SCC and the percentage of neutrophils. However, no consensus exists regarding whether the SCC and percentage of neutrophils are affected in neighboring quarters during infection (Wever and Emanuelson, 1989; Merle et al., 2007; Schwarz et al., 2011; Jensen et al., 2013). Another fact that should be considered is a compensatory change in milk production between quarters within an udder (Hamann and Reichmuth, 1990), which may lead to higher milk production in the uninfected quarter as milk yield decreases in the infected quarter. Thus, we hypothesized that this effect could also contribute to the nonsignificant difference in SCC observed here, as increases in milk yield in the uninfected quarters may have diluted SCC (Green et al., 2006).

A major factor that affects the signals being detected by neighboring quarters (Jensen et al., 2013) may include the extent of inflammation, which is related to the pathogenicity of the mastitis-causing bacteria, the amount of affected tissue (Pyörälä, 2003; Merle et al., 2007; Jensen et al., 2013), and the individual cattle immune response (Burvenich et al., 2003; Petzl et al., 2008), which together might lead to the lack of statistical significance here. For instance, Merle et al. (2007) showed that neutrophil viability in uninfected quarters of uninfected udders was lower than that in uninfected quarters from cows with severe mastitis, but no significant difference was observed when they compared uninfected quarters from uninfected udders with uninfected quarters from cows with moderate mastitis.

Although it is agreed that the immune response against an invading pathogen differs significantly depending on the bacterial species (Schukken et al., 2011; Souza et al., 2012), the percentage of neutrophils did not differ between uninfected quarters from udders with different infection statuses in the current study, although the expression of the adhesion molecules CD11b, CD62L, and CD44 by milk neutrophils was significantly different. The expression of these molecules is induced by the inflammatory response, and they are involved in mobilization of neutrophils to the site of infection (Paape et al., 2003; Gonen et al., 2008). Thus, we hypothesized that the expression of these adhesion molecules by milk neutrophils may more accurately detect the influence of IMI on the neighboring uninfected quarters than SCC or neutrophil percentages, because a slight increase in SCC or the proportion of neutrophils may not be easily detected due to milk yield dilution or the concomitant augmentation of other leukocyte populations, respectively.

Although the study size is limited, our data support the hypothesis of interdependence of quarters based on the influence of the udder infection on the percentage of $\mathrm{B}$ cells in uninfected quarters. Here, a higher percentage of $\mathrm{CD} 21^{+}$cells was found in infected quarters (15.92 \pm $1.84 \% ; \mathrm{n}=6)$, as previously reported by Schwarz et al. (2013) and Riollet et al. (2001), which may explain the increased percentage of $\mathrm{B}$ cells in the neighboring quarters encountered here. This finding may be related to local lymphocyte proliferation (Concha et al., 1996) and the development of a humoral response (Riollet et al., 2001).A higher percentage of $\mathrm{T}$ cells $\left(\mathrm{CD}^{+}\right)$was observed in infected quarters $(13.64 \pm 5.35 \%$; $\mathrm{n}=6)$, as previously described by Rivas et al. (2002) after challenge with $S$. aureus. Nevertheless, it did not have a strong influence on the neighboring uninfected quarters, as no significant difference in the percentage of $\mathrm{T}$ cells or T lymphocyte subsets was found in uninfected quarters from udders with different infection statuses.

It is known that $\mathrm{CD} 21^{+}$cells are increased in milk samples with high SCC, whereas the proportions of $\mathrm{CD}^{+}$and $\mathrm{CD}^{+}{ }^{\text {cells }}$ are decreased (Rivas et al., 2007; Schwarz et al., 2013). The $\mathrm{CD} 2^{+} / \mathrm{CD} 21^{+}$index has recently been proposed as a new marker for the rapid differentiation of normal versus diseased udder quar- 
ters (Schwarz et al., 2013). Regarding our findings, the increase in the proportion of CD21 $1^{+}$cells in uninfected quarters from infected udders may affect the predictive value of the $\mathrm{CD} 2^{+} / \mathrm{CD} 21^{+}$index for diagnosing IMI and therefore requires further investigation.

\section{CONCLUSIONS}

Our study strongly supports the hypothesis of the interdependence of quarters based on the influence of infections on both the percentage of $\mathrm{B}$ cells and the expression of adhesion molecules (CD11b, CD44, and CD62L) by milk neutrophils in neighboring uninfected quarters. Thus, future studies are required to assess the influence of infected quarters in neighboring uninfected quarters on the predictive values of some indicators of inflammation used in the diagnosis of mastitis and on the longitudinal influence of the infection by different pathogens on the immune response of neighboring uninfected quarters.

\section{ACKNOWLEDGMENTS}

The authors are grateful for financial support from the São Paulo State Research Foundation [Fundação de Amparo à Pesquisa do Estado de São Paulo (FAPESP) Project no. 2009/50672-0]. The authors declare that they have no competing interests. MGB and FNS designed the experiments, performed all analyses, drafted the paper, and carried out the statistical analyses; BPS, CFB, and ACP participated in the flow cytometric analyses; LFFA collected all of the samples and provided technical assistance; AMMPDL and MMOPC designed the experiments, supervised the studies, and edited the manuscript.

\section{REFERENCES}

Bansal, B. K., J. Hamann, N. T. Grabowskit, and B. Singh. 2005. Variation in the composition of selected milk fraction samples from healthy and mastitic quarters, and its significance for mastitis diagnosis. J. Dairy Res. 72:144-152.

Barkema, H. W., Y. H. Schukken, T. J. G. M. Lam, D. T. Galligan, M. L. Beiboer, and A. Brand. 1997. Estimation of interdependence among quarters of the bovine udder with subclinical mastitis and implications for analysis. J. Dairy Sci. 80:1592-1599.

Berry, D. P., and W. J. Meaney. 2006. Interdependence and distribution of subclinical mastitis and intramammary infection among udder quarters in dairy cattle. Prev. Vet. Med. 75:81-91.

Blagitz, M. G., F. N. Souza, B. P. Santos, C. F. Batista, A. C. Parra, L. F. F. Azevedo, and A. M. M. P. Della Libera. 2013. Function of milk polymorphonuclear neutrophil in bovine mammary glands infected Corynebacterium bovis. J. Dairy Sci. 96:3750-3757.

Burvenich, C., V. Van Merris, J. Mehrzad, A. Diez-Fraile, and L. Duchateau. 2003. Severity of E. coli mastitis is mainly determined by cow factors. Vet. Res. 34:521-564.

Concha, C., S. Hu, and O. Holmberg. 1996. The proliferative responses of cow stripping milk and blood lymphocytes to pokeweed mitogen and ginseng in vitro. Vet. Res. 27:107-115.
Della Libera, A. M. M. P., F. N. Souza, C. F. Batista, B. P. Santos, L. F. F. Azevedo, E. M. R. Sanchez, S. A. Diniz, M. X. Silva, J. P. Haddad, and M. G. Blagitz. 2015. Effect of bovine leukemia virus infection on milk neutrophil function and the milk lymphocyte profile. Vet. Res. 46:2. http://dx.doi.org/10.1186/s13567-0140125-4.

Diez-Fraile, A., E. Meyer, M. J. Paape, and C. Burvenich. 2003. Analysis of the selective mobilization of L-selectin and Mac-1 reservoirs in bovine neutrophils and eosinophils. Vet. Res. 34:57-70.

Gonen, E., S. Nedvetzki, D. Naor, and N. Y. Shpigel. 2008. CD44 is highly expressed on milk neutrophils in bovine mastitis and plays a role in their adhesion to matrix and mammary epithelium. Vet. Res. 39:29.

Green, L. E., Y. H. Schukken, and M. J. Green. 2006. On distinguishing cause and consequence: Do high somatic cell counts lead to lower milk yield or does high milk yield lead to lower somatic cell count? Prev. Vet. Med. 76:74-89.

Hamann, J., and J. Reichmuth. 1990. Compensatory milk production within bovine udders: effects of short-term non-milking of single quarters. J. Dairy Res. 57:17-22.

Hasui, M., Y. Hirabayashi, and Y. Kobayashi. 1989. Simultaneous measurement by flow cytometry of phagocytosis and hydrogen peroxide production of neutrophils in while blood. J. Immunol. Methods 117:53-58.

Jensen, K., J. Güntler, R. Talbot, W. Petzl, H. Zerbe, H. J. Schuberth, H. M. Seyfert, and E. J. Glass. 2013. Escherichia coli- and Staphylococcus aureus-induced mastitis differentially modulate transcriptional responses in neighboring uninfected bovine mammary gland quarters. BMC Genomics 14:36.

Koess, C., and J. Hamann. 2008. Detection of mastitis in the bovine mammary gland by flow cytometry at early stages. J. Dairy Res. $75: 225-232$.

Mehrzad, J., L. Duchateau, and C. Burvenich. 2004. Viability of milk neutrophils and severity of bovine coliform mastitis. J. Dairy Sci. 87:4150-4162.

Mehrzad, J., L. Duchateau, and C. Burvenich. 2005. High milk neutrophil chemiluminescence limits the severity of bovine coliform mastitis. Vet. Res. 36:101-116.

Merle, R., A. Schröder, and J. Hamann. 2007. Cell function in the bovine mammary gland: A preliminary study on interdependence of healthy and infected udders quarters. J. Dairy Res. 74:174-179.

Oliver, S. P., R. N. González, J. S. Hogan, B. M. Jayarao, and W. E. Owens. 2004 Microbiological Procedures for the Diagnosis of Bovine Udder Infection and Determination of Milk Quality. National Mastitis Council, Verona, WI.

Paape, M. J., D. D. Bannerman, X. Zhao, and J. W. Lee. 2003. The bovine neutrophil: structure and function in blood and milk. Vet. Res. 34:597-627.

Petzl, W., H. Zerbe, N. Güntler, W. Yang, H. M. Seyfert, G. Nurnberg, and H. J. Schuberth. 2008. Escherichia coli, but not Staphylococcus aureus triggers an early increased expression of factors contributing to the innate immune defense in the udder of the cow. Vet. Res. 39:18.

Piepers, S., and S. De Vliegher.. 2013. Oral supplementation of medium-chain fatty acids during the dry period supports the neutrophil viability of peripartum dairy cows. J. Dairy Res. 80:309-318.

Piepers, S., L. De Meulemeester, A. de Kruif, G. Opsomer, H. W. Barkema, and S. De Vliegher. 2007. Prevalence and distribution of mastitis pathogens in subclinically infected dairy cows in Flanders, Belgium. J. Dairy Res. 74:478-483.

Piepers, S., S. De Vliegher, K. Demeyere, B. N. Lamrecht, A. Kruif, E. Meyer, and G. Opsomer. 2009. Technical note: Flow cytometric identification of bovine milk neutrophils and simultaneous quantification of their viability. J. Dairy Sci. 92:626-631.

Pyörälä, S. 2003. Indicators of inflammation in the diagnosis of mastitis. Vet. Res. 34:565-578.

Riollet, C., P. Rainard, and B. Poutrel. 2001. Cell subpopulations and cytokine expression in cow milk in response to chronic Staphylococcus aureus infection. J. Dairy Sci. 84:1077-1084.

Rivas, A. L., S. J. Schwager, R. N. González, F. W. Quimby, and K. L. Anderson. 2007. Multifactorial relationships between intrama- 
mmary invasion by Staphylococcus aureus and bovine leukocyte markers. Can. J. Vet. Res. 71:135-144.

Rivas, A. L., R. Tadevosyan, F. W. Quimbly, and D. H. Lein. 2002. Blood and milk cellular immune responses of mastitic non-periparturient cows inoculated with Staphylococcus aureus. Can. J. Vet. Res. 66:125-131.

Schepers, A. J., T. J. G. M. Lam, Y. H. Schukken, J. B. M. Wilmink, and W. J. A. Hanekamp. 1997. Estimation of variance components for somatic cell counts to determine threshold for uninfected quarters. J. Dairy Sci. 80:1833-1840.

Schukken, Y. H., J. Günther, J. Fitzpatrick, M. C. Fontaine, L. Goetze, O. Holst, J. Leigh, W. Petzl, A. Sipka, D. G. E. Smith, R. Quesnell, J. Watts, R. Yancey, H. Zerbe, A. Gurjar, R. N. Zadoks, and H.-M. Seyfert., and members of the Pfizer Mastitis Research Consortium. 2011. Host-response patterns of intramammary infections in dairy cattle. Vet. Immunol. Immunopathol. 144:270-289.

Schukken, Y. H., D. J. Wilson, F. Welcome, L. Garrison Tikofsky, and R. N. Gonzales. 2003. Monitoring udder health and milk quality using somatic cell counts. Vet. Res. 34:579-596.

Schwarz, D., U. S. Diesterbeck, S. König, K. Brügemann, K. Schlez, M. Zschöck, W. Wolter, and C. P. Czerny. 2011. Flow cytometric differential cell counts in milk for the evaluation of inflammatory reactions in clinically healthy and subclinically infected bovine mammary quarters. J. Dairy Sci. 94:5033-5044.

Schwarz, D., A. L. Rivas, S. König, U. S. Diesterbeck, K. Schlez, M. Zschöck, W. Wolter, and C. P. Czerny. 2013. CD2/CD21 index: A new marker to evaluate udder health in dairy cows. J. Dairy Sci. 96:5106-5119.

Sol, J., O. C. Sampimon, H. W. Barkema, and Y. H. Schukken. 2000 Factors associated with cure after therapy of clinical mastitis caused by Staphylococcus aureus. J. Dairy Sci. 83:278-284.

Souza, F. N., E. M. Ramos Sanchez, M. B. Heinemann, M. A. Gidlund, L. C. Reis, M. G. Blagitz, A. M. M. P. Della Libera, and M. M. O. P. Cerqueira. 2012. The innate immunity in bovine mastitis: The role of pattern-recognition receptors. Am. J. Immunol. 8:166-178.

Van Oostveldt, K., M. J. Paape, H. Dosogne, and C. Burvenich. 2002. Effect of apoptosis on phagocytosis, respiratory burst and CD18 adhesion receptor expression of bovine neutrophils. Domest. Anim. Endocrinol. 22:37-50.

Wever, P., and U. Emanuelson. 1989. Effects of systematic influences and intramammary infection on differential and total somatic cell counts in quarter milk samples of dairy cows. Acta Vet. Scand. $30: 465-474$. 